\title{
DIURNAL FLUCTUATIONS OF TESTOSTERONE AND LH IN THE RAM: EFFECT OF HCG AND GONADOTROPHIN-RELEASING HORMONE
}

\author{
R. E. FALVO,* A. E. BUHL, T. J. REIMERS, $\uparrow$ G. R. FOXCROFT, $\ddagger$ \\ MARY HUNZIGKER DUNN囚 AND P. J. DZIUK \\ Department of Animal Science-Genetics and Department of Zoology, \\ University of Illinois, Urbana, Illinois 61801, U.S.A.
}

(Received 23rd Fuly 1974)

\begin{abstract}
Summary. To examine a possible relationship between the release of LH and increasing testosterone levels, blood samples were collected at 2-hr intervals for $24 \mathrm{hr}$ from six mature rams with indwelling jugular cannulae. Although high levels of LH often preceded increases of testosterone, a consistent time relationship between these two hormones was not observed, nor was a diurnal rhythm established for either hormone. The following day, two rams were each injected intravenously with saline, 500 i.u. HCG, or $100 \mu$ g synthetic gonadotrophinreleasing hormone (Gn-RH) respectively. Immediately after the injection, blood was collected every $15 \mathrm{~min}$ for approximately $4 \mathrm{hr}$. After Gn-RH, the plasma $\mathrm{LH}$ rose 25- to 50-fold within $12 \mathrm{~min}$ and was elevated for more than $3 \mathrm{hr}$. A twofold rise of plasma testosterone followed this increase of $\mathrm{LH}$ and testosterone remained high until the end of the experiment. After HCG treatment, the level of testosterone rose threefold within $30 \mathrm{~min}$ and did not decline during the experiment, but there was no effect on the LH level. Saline treatment did not influence levels of $\mathrm{LH}$ or testosterone.

It was concluded that daily fluctuations of testosterone and $\mathrm{LH}$ may occur independently, and no pattern is common to all rams. Treatment with $\mathrm{Gn}-\mathrm{RH}$ results in a rise in both the testosterone and LH levels, but only testosterone is affected by HCG.
\end{abstract}

\section{INTRODUCTION}

The concentrations of testosterone and $\mathrm{LH}$ are known to fluctuate in the peripheral plasma of the male, but the existence of diurnal rhythms and the

\footnotetext{
* Present address: School of Medicine and Department of Physiology, Southern Illinois University, Carbondale, Illinois 62901, U.S.A.

† Present address: Department of Physiology and Biophysics, Colorado State University, Fort Collins, Colorado 80521, U.S.A.

¥ Present address: Department of Physiology and Environmental Studies, University of Nottingham School of Agricultural Sciences, Sutton Bonington, Loughborough, Leicestershire LE1 25RD.

$\$$ Present address: Northwestern University Medical Center, Chicago, Illinois 60611, U.S.A.
} 
temporal relationship between these two hormones have been examined in only a few species. In the bull, peaks of testosterone follow peaks of LH (Katongole, Naftolin \& Short, 1971) and sexual stimulation, and occasionally ejaculation, caused an increase of $\mathrm{LH}$ in the peripheral plasma, but these LH peaks were not always followed by a testosterone peak. In the male miniature pig, a clear response of plasma testosterone to major changes in plasma LH induced by releasing factor was seen but there was a low correlation between normal $\mathrm{LH}$ release and changes in plasma testosterone (Pomerantz, Ellendorf, Elsaesser, Konig \& Smidt, 1974). Copulation, or the mere presence of the doe, resulted in a significant rise of testosterone in the peripheral plasma of the male rabbit (Saginor \& Hortin, 1968; Haltmeyer \& Eik-Nes, 1969). Studies in men have shown rapid fluctuations of both LH and testosterone in the peripheral plasma, and there are conflicting data showing both the presence and an absence of a diurnal rhythm of these two hormones (Resko \& Eik-Nes, 1966; Nankin \& Troen, 1971; Alford \& co-authors, 1973).

Recent data on the ram have shown that $\mathrm{LH}$ and testosterone are released episodically but there is no evidence of a diurnal rhythm for either hormone (Bolt, 1971; Katongole et al., 1974; Purvis, Illius \& Haynes, 1974; Sanford, Winter, Palmer \& Howland, 1974). In the ram, the secretory pattern of these hormones is also affected by the season. Peaks of LH appeared more frequently but the amplitude was either similar or depressed during the breeding season (Katongole et al., 1974; Sanford et al., 1974). Testosterone peaks during the breeding season displayed both higher amplitude and frequency (Katongole et al., 1974; Purvis et al., 1974; Sanford et al., 1974). Furthermore, in studies where both LH and testosterone were measured, testosterone peaks were always shown to be preceded by an LH peak (Katongole et al., 1974; Sanford et al., 1974).

The present study was designed to examine changes of LH and testosterone in the peripheral plasma of adult rams during a 24-hr period. In addition, HCG and synthetic gonadotrophin-releasing hormone (Gn-RH) were administered to observe the effects of these hormones on $\mathrm{LH}$ and testosterone in the peripheral plasma. These experiments were designed to determine the temporal relationship, if any, between $\mathrm{LH}$ release, either naturally occurring or artificially induced, and testosterone secretion.

\section{MATERIALS AND METHODS}

During the breeding season in September, six adult Hampshire rams each weighing $110 \mathrm{~kg}$ were placed in outdoor pens, isolated from ewes, 1 week before the experiment. Blood samples were collected from indwelling jugular cannulae which had been inserted 1 day previously. Samples were taken every $2 \mathrm{hr}$ for $24 \mathrm{hr}$. After the $24-\mathrm{hr}$ collection, two rams each were injected intravenously with saline, 500 i.u. HCG (APL:Ayerst Laboratories, New York) or $100 \mu \mathrm{g}$ Gn-RH respectively. Blood was collected every $15 \mathrm{~min}$ for $1 \mathrm{hr}$ before and for approximately $4 \mathrm{hr}$ after an injection.

Plasma LH was assayed using the double antibody radioimmunoassay (RIA) as described previously by Niswender, Reichert, Midgley \& Nalbandov (1969), with some modifications. Ovine LH (LER-1056-C2) was iodinated using ${ }^{125}$ I, 
according to the method of Greenwood, Hunter \& Glover (1963). The first antibody used in these assays was No. 15 of Niswender which has been shown to be specific for ovine LH (Niswender, Midgley \& Reichert, 1968). Samples of plasma were assayed in duplicate at 100 or $200 \mu \mathrm{l}$ and NIH-LH-S13 was used as the ovine standard. Using these volumes of plasma, the acceptable range of the assays was 0.17 to $30.0 \mathrm{ng} / \mathrm{ml}$. For statistical purposes, values below the

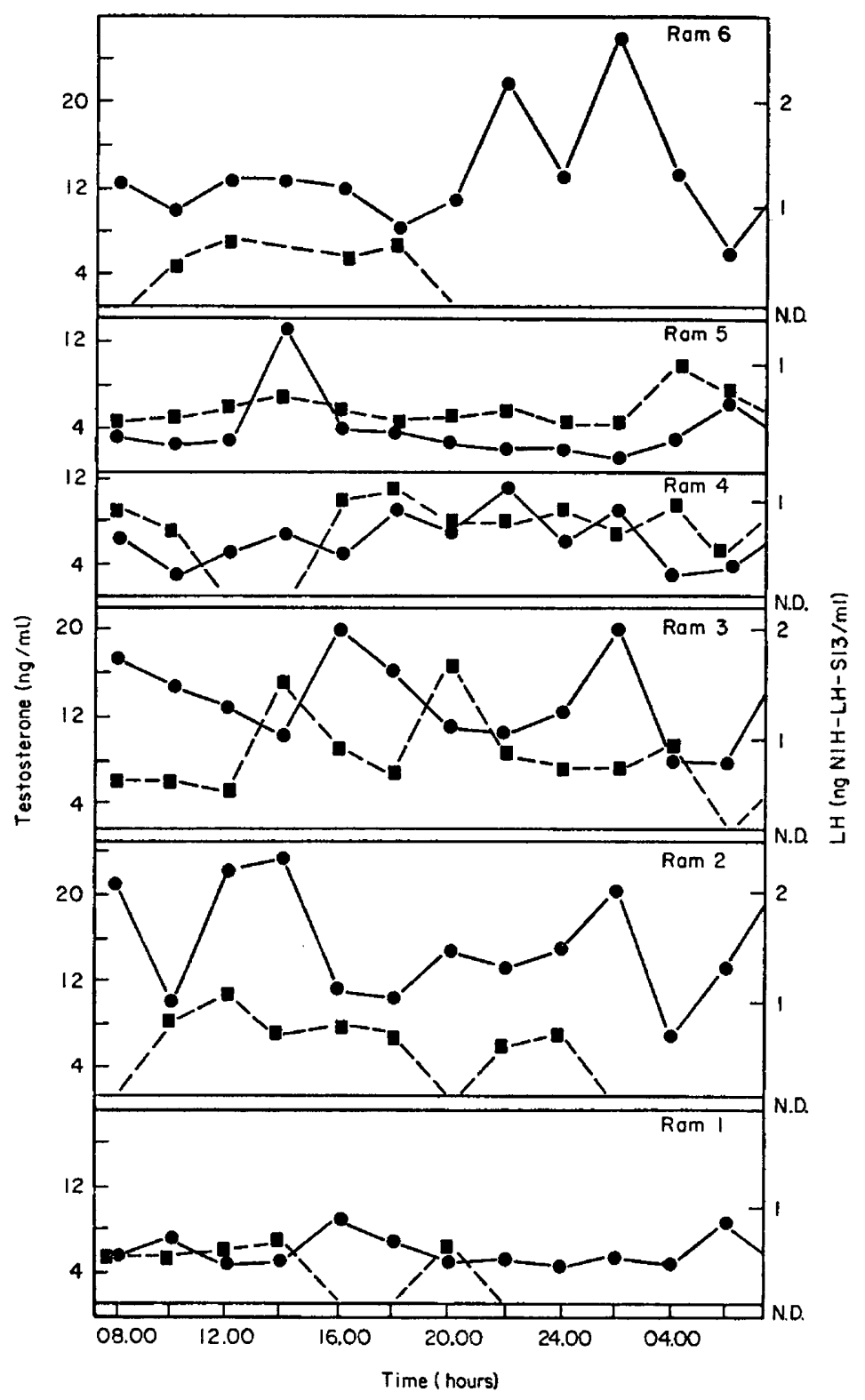

Texr-FIG. 1. Daily (24-hr) fluctuations of testosterone (๑) and LH ( $\square$ ) in the peripheral blood of six rams. N.D. = not detectable. 
sensitivity of the assays were assigned a value of $0.17 \mathrm{ng} / \mathrm{ml}$ and those above the upper range of the assays, a value of $30.0 \mathrm{ng} / \mathrm{ml}$. The inter-assay coefficient of variation was $11 \%$.

The RIA used for plasma testosterone was similar to that of Bartke, Steele, Musto \& Caldwell (1973), the modifications used in our laboratory having been described previously (Falvo, Buhl \& Nalbandov, 1974). The antiserum used was specific to testosterone and dihydrotestosterone. All samples were run in duplicate using either 10 or $20 \mu \mathrm{l}$ plasma without chromatography. This procedure and validation for the testosterone RIA in rams has been previously published by our laboratory (Falvo \& Nalbandov, 1974).

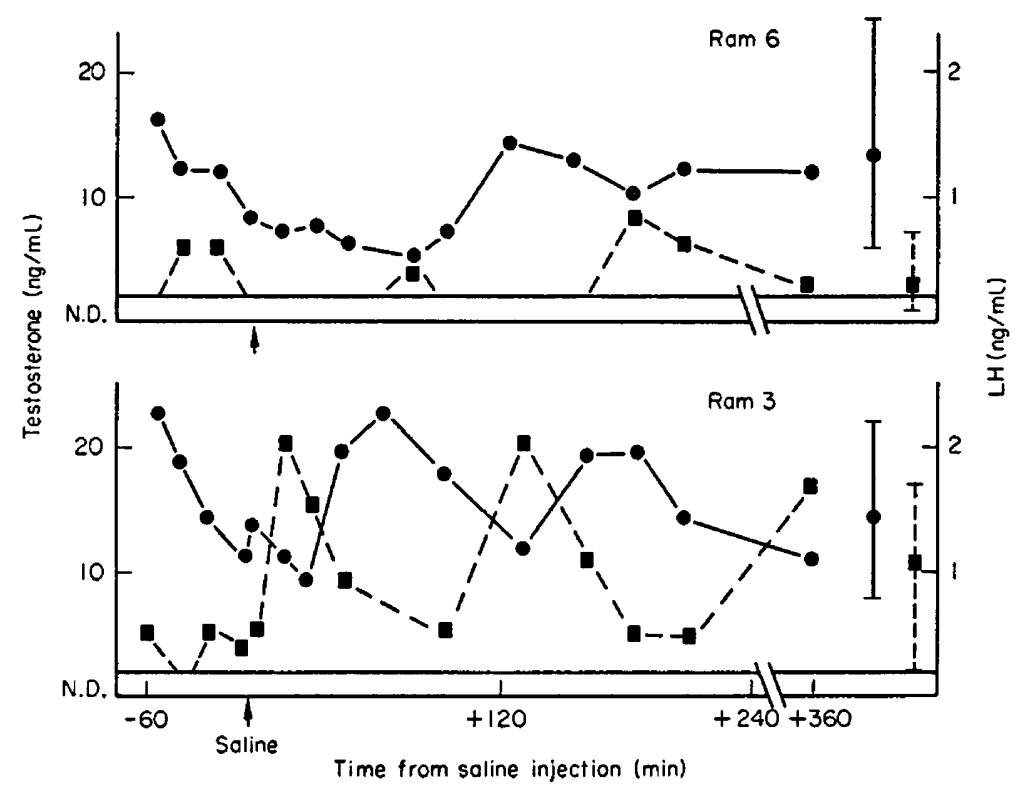

Text-rig. 2. The response of plasma testosterone $(\bullet)$ and LH $(\boldsymbol{\omega})$ to an intravenous injection of saline. The average and range for testosterone and $\mathrm{LH}$ was measured the day previously in the same ram and served as the control (vertical bars, right side of figure). N.D. = not detectable.

When $\left[{ }^{3} \mathrm{H}\right]$ testosterone was added to $10-\mu 1$ aliquots of wether plasma, the mean recovery of $20,000 \mathrm{ct} / \mathrm{min}$ was $97.0 \%$. Standard curves from six different assays showed a coefficient of variation of $2.4 \%$ at the lowest concentration on the curve $(3.7 \mathrm{pg})$ to $11.9 \%$ at the highest point $(500.0 \mathrm{pg})$. The recovery (Mean \pm S.E.) of $31.2,62.5$ and $125.0 \mathrm{pg}$ testosterone from $10 \mu \mathrm{l}$ wether plasma was $20 \cdot 7 \pm 6 \cdot 8(n=4), 48 \cdot 7 \pm 2 \cdot 1(n=8)$, and $105 \cdot 8 \pm 4 \cdot 3(n=4) \mathrm{pg} / \mathrm{ml}$, respectively. The lowest amount of testosterone which was measurable repeatedly and distinguishable from zero was $13.4 \pm 1.7 \mathrm{pg}$. The specificity of the method was examined by analysis of twenty samples of wether plasma. All samples contained non-detectable quantities of testosterone. The variations between duplicates was less than $10 \%$ in all cases and therefore the plotted values will not show the standard errors. 


\section{RESULTS}

Text-figure 1 shows the changes for both $\mathrm{LH}$ and testosterone in samples collected every $2 \mathrm{hr}$ for $24 \mathrm{hr}$. Concentrations of testosterone ranged from 1.6 to $26.0 \mathrm{ng} / \mathrm{ml}$, and the levels of $\mathrm{LH}$ ranged from non-detectable to $1.8 \mathrm{ng} / \mathrm{ml}$. In Rams 2 and 3, an LH-testosterone relationship was seen which was not observed in other rams. The time interval from a 'peak' of $\mathrm{LH}$ to a peak in testosterone varied from $2 \mathrm{hr}$ to $6 \mathrm{hr}$. However, because of the absence of this relationship in most of the rams, the lack of any time consistency between LH and testosterone, and the infrequent sampling time, the physiological importance of these observations is not clear. The mean $\mathrm{LH}$ and testosterone

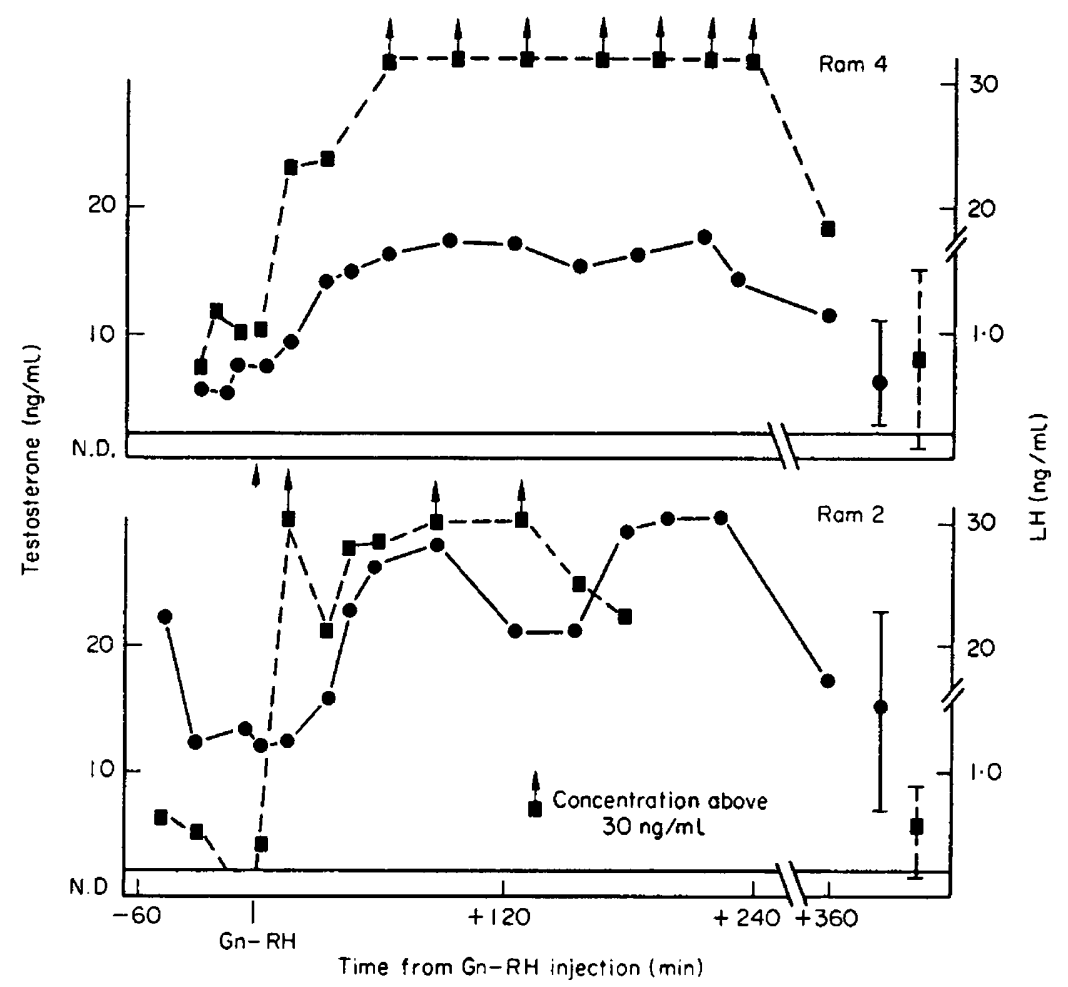

TExT-Fig. 3. The response of plasma testosterone ( $)$ and $L H(\boldsymbol{D})$ to an intravenous injection of $\mathrm{Gn}-\mathrm{RH}$. The average and range for testosterone and $\mathrm{LH}$ was measured the day previously in the same ram and served as the control (vertical bars, right side of figure). N.D. = not detectable.

concentrations over the 24-hr period were used as control values for comparison with the levels observed after administration of saline, HCG, or Gn-RH. These control values (average and range) appear at the right side of Text-figs 2, 3 and 4.

During the 24-hr collection period, a diurnal rhythm could not be established for either hormone in individual rams. When the mean levels of plasma testosterone and LH of all six rams were taken together, a diurnal rhythm was still 
not apparent. Text-figure 2 shows the levels of testosterone and LH following saline injection. In Ram 3, no difference was observed in plasma testosterone and LH following saline administration compared to the control values of these hormones measured the previous day (right side of figure). With frequent sampling, however, a time relationship between plasma LH and testosterone was apparent. There was a rise in plasma testosterone within 48 to $50 \mathrm{~min}$ following an $\mathrm{LH}$ peak. The two $\mathrm{LH}$ peaks occurred $4 \mathrm{hr}$ apart. In Ram 6, no time relationship between $\mathrm{LH}$ and testosterone could be established. A similar relationship to that found in Ram 3 may have been present but, owing to the low circulating levels of $\mathrm{LH}$, definitive peaks could not be measured.



TExT-riG. 4. Response of plasma testosterone $(\bullet)$ and LH ( $(\square)$ to intravenous injections of HCG. The average and range for testosterone and LH was measured the day previously in the same ram and served as the control (vertical bars, right side of figure). N.D. = not detectable.

Following the injection of $100 \mu \mathrm{g} \mathrm{Gn-RH} \mathrm{(Rams} 2$ and 4, Text-fig. 3), there was a rise in plasma $\mathrm{LH}$ within $12 \mathrm{~min}$ to a level which was 30 -fold above the control values shown at the right side of the figure. The LH concentrations in Ram 4 were elevated for over $4 \mathrm{hr}$ after Gn-RH injection. Testosterone concentrations following $\mathrm{Gn}-\mathrm{RH}$ rose to significantly higher levels in both rams within a mean \pm S.E. time of $55 \pm 5 \mathrm{~min}$ or within $43 \pm 5 \mathrm{~min}$ after the induced LH peaks.

After administration of HCG to Ram 1 and Ram 5 (Text-fig. 4), no rise in LH was observed, but the testosterone concentrations in both rams rose significantly above the control values, three- to fivefold within $30 \mathrm{~min}$ and four- to tenfold $66 \mathrm{~min}$ after HCG. The second HCG injection did not elicit any further increase in the testosterone levels in either ram. 


\section{DISCUSSION}

No consistent time relationship between peripheral testosterone and LH was noted over a 24-hr period in rams under the conditions of this study. The LH release observed appears to represent only small excursions from basal levels, confirming earlier work which showed that $\mathrm{LH}$ was released in brief surges rather than at a continuous rate with no diurnal variation during the collection period (Bolt, 1971). The physiological significance of this release is not understood. Furthermore, in order realistically to determine a possible relationship between LH and testosterone, more frequent sampling may be necessary. The fluctuations of the peripheral testosterone concentrations appeared to be independent of the $\mathrm{LH}$ peaks in all except two animals, and showed no variation with respect to the time of day. In more recent studies in which blood was collected at $20 \mathrm{~min}$ intervals, a consistent pattern between these two hormones was found (Sanford et al., 1974). These workers noted that although, among rams, LH releases were occurring at random, in individual rams they occurred at regular intervals and were always followed by increases in plasma testosterone.

The response of plasma $\mathrm{LH}$ following injection of $\mathrm{Gn}-\mathrm{RH}$ was both rapid and prolonged. These responses to synthetic Gn-RH appear to be greater than those reported in the intact ram by Reeves, Arimura \& Schally (1970) in response to a purified porcine hypothalamic LH-releasing hormone extract.

This pattern of response to Gn-RH injection ( $\mathrm{LH}$ increase followed by testosterone increase) observed in the present studies with the ram is similar to that reported by other workers for the male miniature pig (Pomerantz et al., 1974), and the responses of plasma testosterone to injection of $\mathrm{HCG}$ are similar to those found in other animals. Marked increases in plasma testosterone in response to HCG treatment have been reported for the human male (Lipsett \& coauthors, 1966), the bull (Katongole et al., 1971), the rabbit (Saginor \& Hortin, 1968) and the rat (Bardin \& Peterson, 1967).

It is concluded that when blood samples were taken every $2 \mathrm{hr}$ for $24 \mathrm{hr}$ in the ram and measured for $\mathrm{LH}$ and testosterone, no consistent time relationship between these two hormones was found, and a diurnal rhythm could not be established for either hormone during this 24-hr period. With more frequent sampling, however, a time relationship between $\mathrm{LH}$ and testosterone was seen in one of the rams. With Gn-RH and HCG a consistent time interval of 30 to $40 \mathrm{~min}$ was demonstrated between administration of these two hormones and testosterone secretion. This appeared to be similar to the interval observed between endogenous LH and testosterone peaks in one animal. This LH-totestosterone time interval is in agreement with that found previously in the ram after frequent blood sampling (Sanford et al., 1974).

\section{AGKNOWLEDGMENT}

The synthetic Gn-RH was generously donated by Abbott Laboratories, Chicago, Illinois.

\section{REFERENCES}

Alford, F. R., Baker, A. W. G., Patel, Y. G., Rennie, G. C., Youati, G., Burger, H. G. \& Hudson, B. (1973) Temporal patterns of circulating hormones as assessed by continuous blood sampling. 7. clin. Endocr. Metab. 36, 108-116. 
Bardin, C. W. \& Peterson, R. E. (1967) Studies of androgen production by the rat: testosterone and androstenedione content of blood. Endocrinology, 80, 38-44.

Bartke, A., Steele, R.E., Musto, N. \& Caldwell, B. V. (1973) Fluctuations of plasma testosterone levels in adult male rats and mice. Endocrinology, 92, 1223-1228.

BoLt, D.J. (1971) Changes in the concentration of luteinizing hormone in the plasma of rams following administration of oestradiol, progesterone, or testosterone. F. Reprod. Fert. 24, 435-438.

Falvo, R. E., Buhz, A. \& Nalbandov, A. V. (1974) Testosterone concentrations in the peripheral plasma of androgenized female rats and in the estrous cycle of normal female rats. Endocrinology, 95, 26-29.

Falvo, R. E. \& Nalbandov, A. V. (1974) Radioimmunoassay of peripheral testosterone in males from eight species using a specific antibody without chromatography. Endocrinology, 95, 1466-1468.

Greenwood, F. G., Hunter, W. M. \& Glover, J. S. (1963) The preparation of ${ }^{13}{ }^{1}$ I-labelled human growth hormone of high specific radioactivity. Biochem. 7. 89, 114-123.

Haltmeyer, G. C. \& Eik-Nes, K. B. (1969) Plasma levels of testosterone in the male rabbit following copulation. F. Reprod. Fert. 19, 273-277.

Katongole, C. B., Naftolin, F. \& Short, R. V. (1971) Relationship between blood levels of luteinizing hormone and testosterone in bulls, and the effects of sexual stimulation. 7. Endocr. 50, 457-466.

Katongole, C. B., Naftolin, F. \& Short, R. V. (1974) Seasonal variations of blood luteinizing hormone and testosterone levels in rams. F. Endocr. 60, 101-106.

LipsetT, M. B., Wilson, H., Kirschner, M. A., Korenman, S. G., Fishman, L. M., Sarfaty, G. A. \& BARDIN, C. W. (1966) Studies in Leydig cell physiology and pathology: secretion and metabolism of testosterone. Recent Prog. Horm. Res. 22, 245-281.

Nankin, H. R. \& Troen, P. (1971) Overnight patterns of serum luteinizing hormone in normal men. J. clin. Endoct. Metab. 35, 705-710.

Niswender, G. D., Midgley, A. R. \& Reichert, L. E. (1968) Radioimmunologic studies with murine, bovine, ovine, and porcine luteinizing hormone. In Gonadotropins. Ed. E. Rosemberg. Geron-X Inc., Los Altos, California.

Niswender, G. D., Reichert, L. E., Midgley, A. R. \& Nalbandov, A. V. (1969) Radioimmunoassay for bovine and ovine luteinizing hormone. Endocrinology, 84, 1166-1173.

Pomerantz, D. K., Ellendorf, F., Elsaesser, F., Konig, A. \& Smidt, D. (1974) Plasma LH changes in intact adult, castrated adult and pubertal male pigs following various doses of synthetic luteinizing hormone-releasing hormone (LH-RH). Endocrinology, 94, 330-335.

Purvis, K., Illuus, A. W. \& Haynes, N. B. (1974) Plasma testosterone concentrations in the ram. 7. Endoct. 61, 241-253.

Reeves, J.J., Arimura, A. \& Schally, A. V. (1970) Studies on dose response relationship of luteinizing hormone-releasing hormone (LH-RH) in sheep. F. Anim. Sci. 31, 933-936.

Resko, J. A. \& Erk-Nes, K. B. (1966) Diurnal testosterone levels in peripheral plasma of human male subjects. F. clin. Endocr. Metab. 26, 573-576.

SAGinor, M. \& Hortin, R. (1968) Reflex release of gonadotrophin and increased plasma testosterone concentration in male rabbits during copulation. Endocrinology, 82, 627-630.

Sanford, L. M., Winter, J.S. D., Palmer, W. M. \& Howland, B. E. (1974) The profile of LH and testosterone secretion in the ram. Endocrinology, 95, 627-631. 